$\xi=$

\title{
Analytical and Experimental Study on Composite Deep beams with Rolled section reinforcement
}

\author{
Konuri Pavani ${ }^{1 *}$, G. Sri Harsha ${ }^{2}$, \\ ${ }^{1}$ Student, Koneru Lakshmaiah Education Foundation \\ ${ }^{2}$ Assistant Professor, Koneru Lakshmaiah Education Foundation \\ *E-mail: pavanikonuri31@gmail.com
}

\begin{abstract}
An experimental study was conducted on three RC Deep beams along with Analytical simulation under three point loading in which one specimen was provided with Rolled section reinforcement. The specimens are designed according to IS 456:2000 . In one specimen the total reinforcement area was replaced with rolled I-Section. Steel plate grade of MS250 of 3mm thickness was molded as rolled I- Section. Various parameters like flexural behavior, shear strength, deflection, crack width, stress and ductility were calculated. For improving the bond strength between steel section and concrete in composite member, shear struts are provided. The length to depth ratio (1/d) was 1.875 and shear span to depth ratio (a/d) was 0.75 . Finite element simulation was carried out by using ANSYS 18.1. and comparison was made in between Analytical and Experimental results.
\end{abstract}

Keywords: Deep beam; Finite Element modeling; Flexural behavior; Rolled I-section; Shear span to Depth ratio.

\section{Introduction}

Different codes define deep beam in their own way. According to IS 456: 2000, the Length to Depth ratio varies based on support conditions. The length to depth ratio for simply supported deep beam and continuous deep beam are 2.0 and 2.5 respectively. According to clause 10.7.1 in ACI 318, the beam is considered as deep beam if the clearspan to overall depth proportion was not exactly or equivalent 4.0 or a series of concentrated loads in a beam within the twice the member depth from the face of the support. British code BS 8110 defines deep beam as the beam having the length to depth ratio between 0.5 to 2.0. The major applications of the deep beam are Bunkers, Silos, water tanks. In some cases, pile caps are also designed as deep beams. In present study results of experimental work were used to evaluate the results of the analytical simulation.

A lot of research has been carried out on deep beams to study its structural behavior both in experimental and analytical methods. How the reinforcement quantity varies with introducing high strength reinforcement in deep beams, for variable shear span to depth ratio was explained[1] ,to predict the deep beam behavior various modes of failure and propagation of cracks were examined[2], the impact of vertical, horizontal web reinforcement of deep beam was efficient in shear capacity and perpendicular reinforcement improve the ultimate shear strength was discussed[3], comparison of deep coupling beams plate anchorage in the wall region with diagonally reinforced coupling beams was made and anchorage plate system achieve more capacity without causing the congestion of steel[4]. All these Studies were carried out on deep beams by fluctuating the parameters like shear span to depth ratio, change in the reinforcement proportion, length to depth ratio etc.
In this examination, a trail was led on deep beam with rolled Isection[5] as reinforcement.

\section{Experimental Programme}

The materials used in concrete were tested before they are cast to find out its properties. In addition, the SP430 admixture was used in concrete to increase its workability. An ordinary Portland cement grade 53 has a specific gravity of 2.65 . Fine aggregates have fineness module 2.68 and specific gravity of 2.324 and the bulk density is 1.52 . A maximum size of $20 \mathrm{~mm}$ and Zone- 2 crushed rock is used as coarse aggregate. The specific gravity and bulk modulus of coarse aggregates are 2.782 and 1.68 respectively

\subsection{Concrete Mix design}

Table 1: Mix proportion of concrete

\begin{tabular}{cccccc}
\hline $\begin{array}{c}\text { Grade of } \\
\text { Concrete }\end{array}$ & $\begin{array}{c}\text { Ce- } \\
\text { ment }(\end{array}$ & $\begin{array}{c}\text { Fine ag- } \\
\text { gregate(\%) }\end{array}$ & $\begin{array}{c}\text { Coarse } \\
\text { aggre- } \\
\text { gate }(\%)\end{array}$ & $\begin{array}{c}\text { w/c } \\
\text { ratio }\end{array}$ & $\begin{array}{c}\text { Admix- } \\
\text { ture }(\%)\end{array}$ \\
\hline M35 & 1 & 1.85 & 3.53 & 0.45 & 0.75 \\
\hline
\end{tabular}

The concrete mix used to cast the specimens are designed by using IS 10262: 2000. For each beam, a conventional concrete cube of dimensions $150 \mathrm{~mm} \times 150 \mathrm{~mm} \times 150 \mathrm{~mm}$ was cast and tested after 28 days in compression testing machine.

\subsection{Design details of Deep beam specimens}


Total three deep beams were cast in which two specimens were provided with conventional reinforcement and one specimen has rolled I-section as its reinforcement. Three members have length $1500 \mathrm{~mm}$, depth $800 \mathrm{~mm}$, width $250 \mathrm{~mm}$. A clear cover of $20 \mathrm{~mm}$ was maintained on all sides. According to IS-456:2000, the design load for deep beams was $780 \mathrm{kN}$ under single point loading condition at a shear span of $600 \mathrm{~mm}$. The reinforcement detailing was done according to Indian Standards for two conventional deep beams and in another deep beam total reinforcement quantity was replaced with mild steel plate of grade MS250 of thickness $3 \mathrm{~mm}$ which was molded as I-section. Extra stiffeners were provided in order to prevent the section from buckling. Shear struts were welded to the I-section to create the bonding between steel and concrete. The specimen details which were shown in Table. 2 used for both experimental and analytical approaches. The detailing for conventional deep beam, I reinforced deep beam in Fig.1, Fig.2 respectively.

Table 2: Geometry Details of Specimens

\begin{tabular}{lccc}
\hline Specimen & \multicolumn{3}{c}{ Geometry Details } \\
\cline { 2 - 4 } & Length $(\mathrm{mm})$ & Width(mm) & Depth(mm) \\
\hline CDB-1 & 1500 & 250 & 800 \\
\hline CBD-2 & 1500 & 250 & 800 \\
\hline IDB & 1500 & 250 & 800 \\
\hline
\end{tabular}

Table 3: Detailing for Conventional Deep beam

\begin{tabular}{|c|c|c|c|c|c|c|c|}
\hline \multirow[b]{2}{*}{$\begin{array}{l}\text { S. } \\
\text { no }\end{array}$} & \multirow[b]{2}{*}{$\begin{array}{l}\text { Spec- } \\
\text { imen }\end{array}$} & \multirow[b]{2}{*}{$\begin{array}{c}\mathrm{L} / \mathrm{d} \\
\text { Ratio }\end{array}$} & \multirow[b]{2}{*}{$\begin{array}{c}\text { a/d } \\
\text { Ratio }\end{array}$} & \multicolumn{2}{|c|}{$\begin{array}{l}\text { Horizontal Rein- } \\
\text { forcement }\end{array}$} & \multicolumn{2}{|c|}{$\begin{array}{l}\text { Vertical Rein- } \\
\text { forcement }\end{array}$} \\
\hline & & & & $\begin{array}{c}\mathrm{A}_{\mathrm{st}} \\
\left(\mathrm{mm}^{2}\right)\end{array}$ & $(\%)$ & $\begin{array}{c}\mathrm{A}_{\mathrm{st}} \\
\left(\mathrm{mm}^{2}\right)\end{array}$ & $(\%)$ \\
\hline & CDB- & & & & 0.942 & & 0.12 \\
\hline 1 & 1 & 1.875 & 0.75 & 1884.95 & 5 & 251.32 & 6 \\
\hline 2 & $\begin{array}{c}\text { CDB- } \\
2\end{array}$ & 1.875 & 0.75 & 1884.95 & 0.942 & 251.32 & $\begin{array}{c}0.12 \\
6\end{array}$ \\
\hline
\end{tabular}
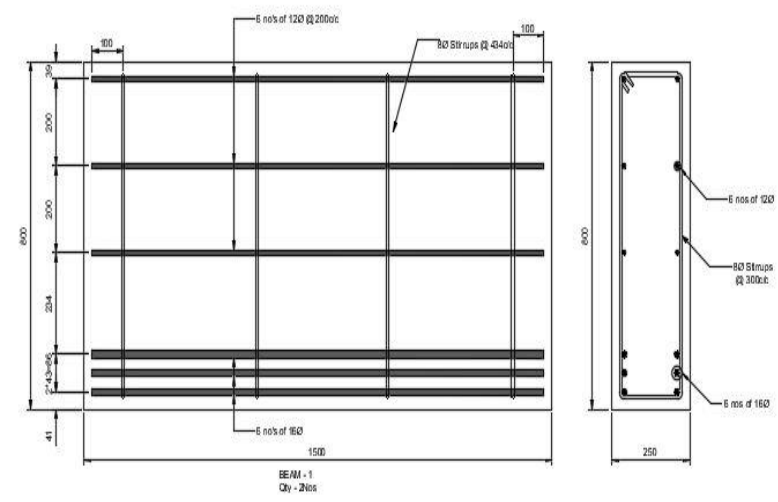

Fig. 1: Reinforcement detailing of conventional deep beam

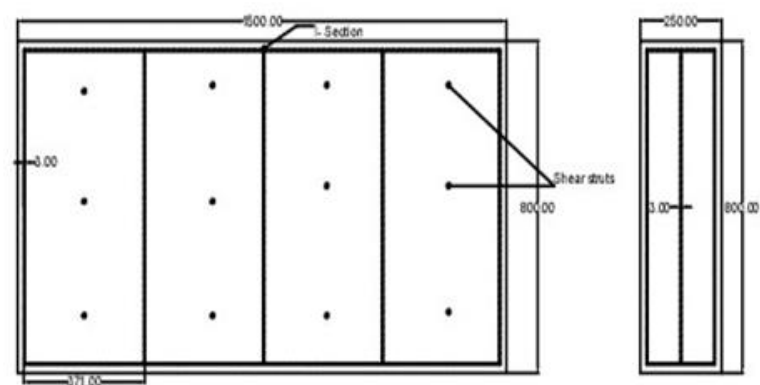

Fig. 2 : Reinforcement detailing of I deep beam

\section{Tests on Deep beams}

All the specimens were tested on loading frame of $2000 \mathrm{kN}$ capacity available at Structures Laboratory. The specimens are tested with simply supported conditions under three point loading. The supported plates itself acts as loading point hence it was called as three point loading condition. Shear span to depth ratio was 0.75 . The surface strain gauges are attached to the beam on two sides. In this experiment, deflection, various mode of failures, crack pattern were studied at a $4 \mathrm{kN} / \mathrm{sec}$ rate of loading. A comparative study was made in between conventionally reinforced deep beam and Rolled section reinforcement deep beam. The test set up was as shown in Fig.3.

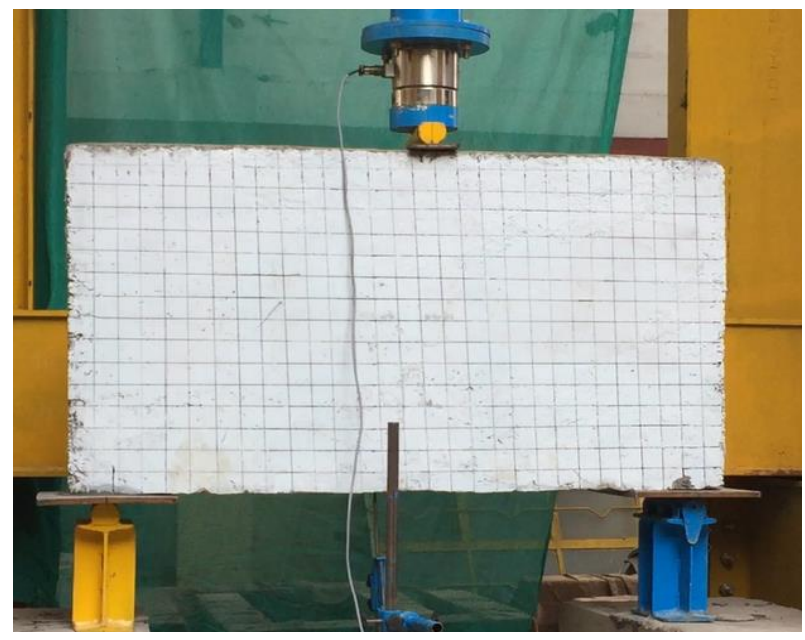

Fig. 3: The test set up for deep beams

\subsection{Analytical Approach}

By using ANSYS workbench 18.1, the modeling of the three specimens was done with the same values of geometry details and reinforcement details as shown in Fig.4, Fig.5 for conventional and I reinforced deep beam respectively. 


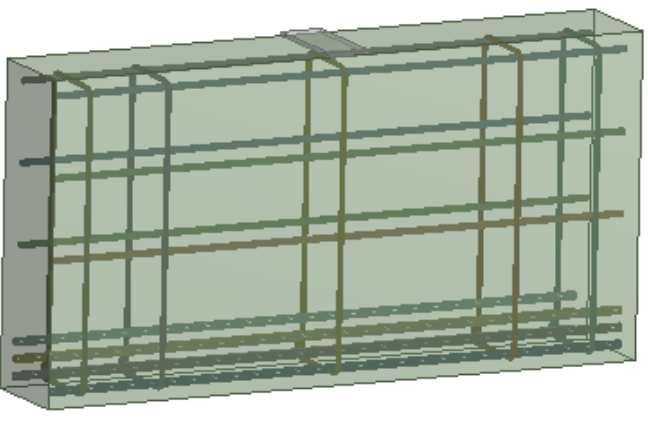

Fig.4 : Analytical Modeling of CDB

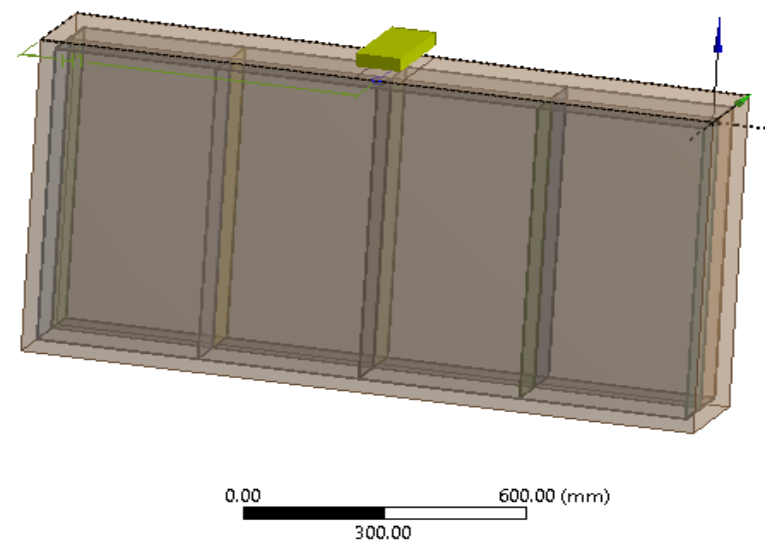

Fig. 5 : Analytical Modeling of IDB

To obtain the accurate results very fine mesh discretization was done, by using that a number of required parameters were solved.

\subsection{Test results of deep beams}

The major parameters observed during testing were a loaddeflection pattern, stress-strain response, crack pattern.

\subsubsection{Load - Deflection response}

The applied load versus deflection response for the all three deep beams as shown in the Fig.6. The experimental and analytical values were nearly similar for all three members. It was observed that the initial stiffness and response to load is different for the specimens. The beam with rolled I-section reinforcement taken more load than the conventional deep beams. For conventional deep beam-1(CDB-1) up to the initial diagonal crack the load increases and at the same deflection the load value raised to maximum load i.e. $920 \mathrm{kN}$ at a deflection of $6 \mathrm{~mm}$ then load decreases. In case of conventional deep beam-2(CDB-2), the load was increased to $927.7 \mathrm{kN}$ at a deflection of $6.51 \mathrm{~mm}$ where the first diagonal crack starts propagating. The third specimen I-section reinforced deep beam(IDB) the flexural crack occurred at 991.5 $\mathrm{kN}$ and the deflection was $7.50 \mathrm{~mm}$ after that the load starts decreasing with increasing the crack width. The overall response of three specimens was the specimens with conventional reinforcement failed in shear whereas the IDB fails initially in Flexure.

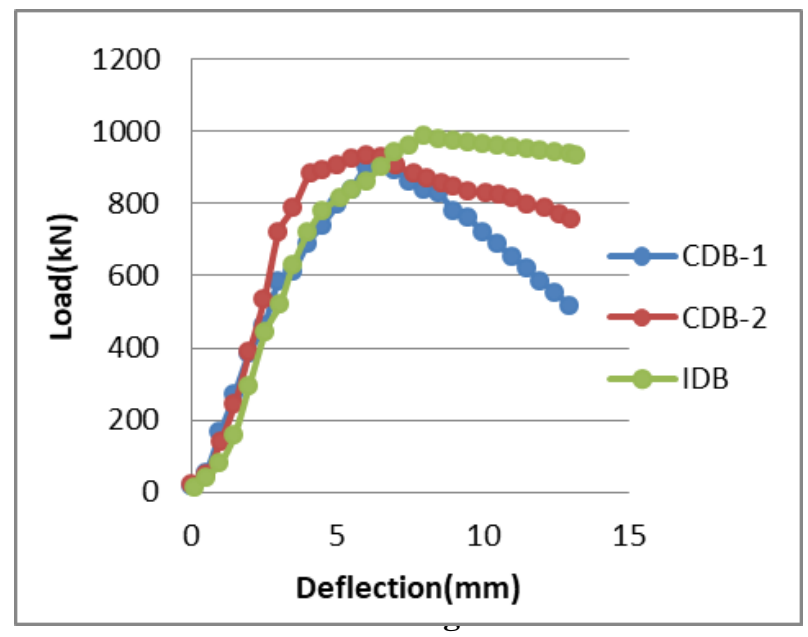

Fig. 6 : Load - deflection response

\subsubsection{Stress - Strain response}

From the finite element analysis and experimental results showing that stresses were developed in the IDB compared to both conventional specimens. At the ultimate load, the ultimate stress was developed. By using the matrix area, fiber an area values modulus of elasticity was determined. Using that value stress corresponding strain was calculated. The analytical results were similar to experimental in case IDB, whereas in CDB-1, CDB-2 the results were somewhat varied. Fig. 7 showing the plot for stress strain response.

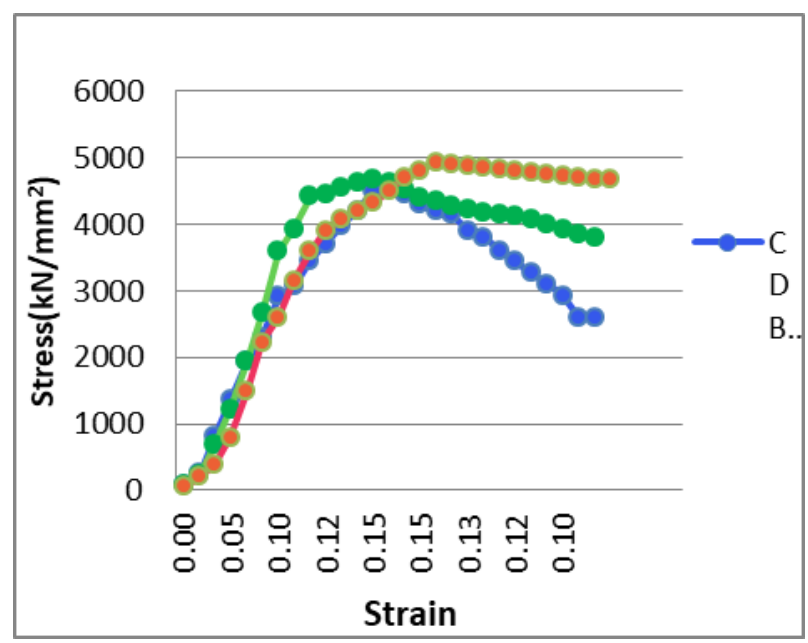

Fig . 7. Stress - strain response

\subsubsection{Crack pattern and Failure modes :}

The initial cracks which are observed are similar for two specimens i.e. for CDB-1, CDB-2 whereas in case of IDB it was different. In two cases shear cracks were developed outer than shear span at constant bending moment region. Further increasing the load Flexural cracks were propagated. The first observed crack IDB was flexural crack. As the load intensity raised spalling of concrete was observed as a local failure and propagated at the load application point. In all, there cases diagonal splitting cracks were observed from the middle depth of the shear span and propagated towards the load application point and form of the shape of an arch, which is called as Arching action in deep beams. Typical modes of failures in Deep beams were shown in Fig. 8 

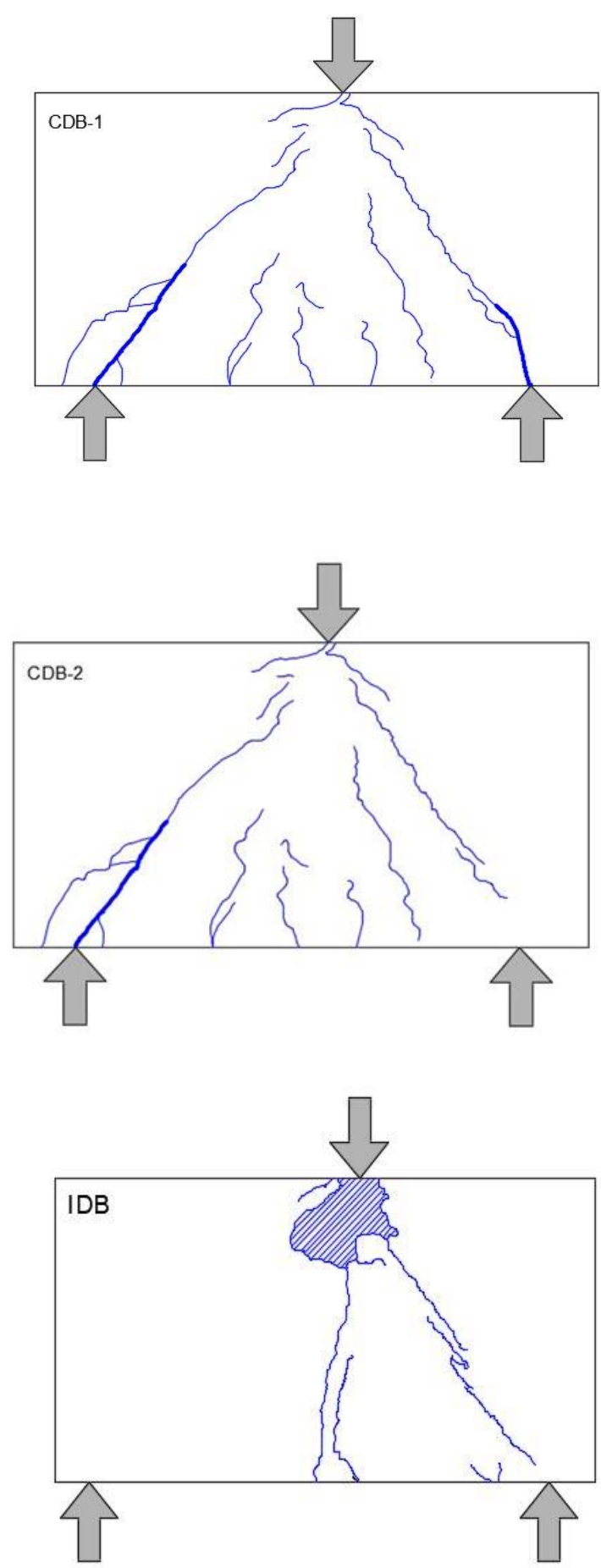

Fig. 8 Digitalized crack pattern for CDB-1, CDB-2, IDB

a) When the cracks engendered towards the load from the support the observed cracks were the diagonal splitting mode of failure.

b) Shear compression failure cracks were engendered after diagonal cracks in the shear span which is an explosive failure.

c) Spalling of concrete leads local compression failure, after yielding of the main steel the Flexural compression failure was developed with crushing of concrete.

\subsubsection{Effect of rolled section reinforcement:}

Placing of rolled section as reinforcement increased the load carrying capacity. The shear resistance provided by means of shear struts and stiffeners throughout the depth influences the load capacity as the crushing of concrete to occur the first. Prior to the formation of non-diagonal cracks, the rolled section reinforcement had a significant effect on the whole behavior of Deep beam. In CDB-1, CDB-2 the modes of failure changed in less amount from shear compression whereas in IDB there was no such type of change.

\subsubsection{Stiffness vs Drift ratio $(\Delta / H)$ response:}

The experimental results showing that deep beam with rolled steel reinforcement was stiffer at low drift ratio than the conventionally reinforced deep beams. From the definition of the drift ratio i.e. ratio of maximum drift to the total height of the specimen. The beam with less proportion of drift value had more yield values. Fig.9 showing the graphical demonstration of stiffness vs. drift ratio.

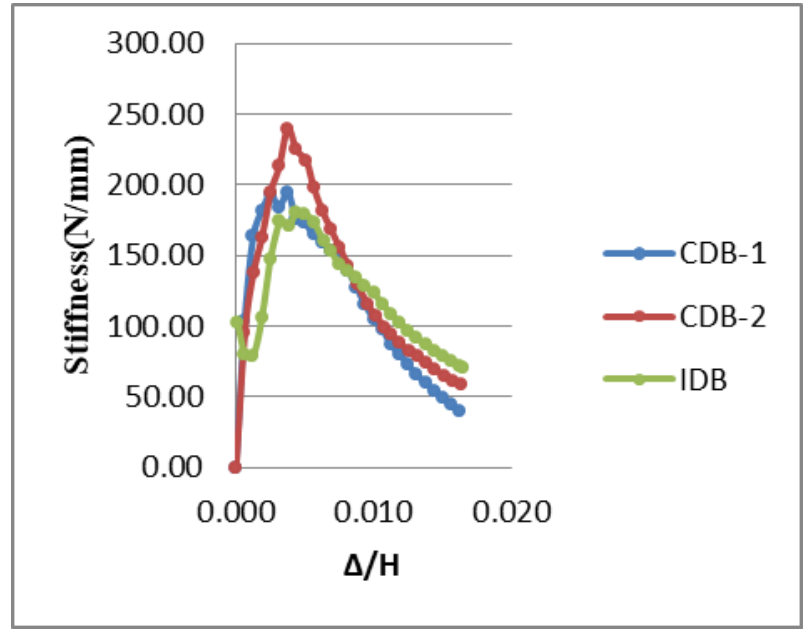

Fig .9 Stiffness vs. drift ratio response

\section{Conclusion}

The Experimental and analytical results presented in this study and evaluation of composite approaches, the following can be concluded

- According to IS 456: 2000, design criteria of conventional deep beams, the major failure was diagonal cracking and crack propagated towards the loading point from the support.

- The failure mechanism and crack pattern were not similar for CDB-1, CDB-2 to those of IDB.

- The load applied on deep beam was greater than design load by $20 \%$ for CDB-1, CDB-2 and 30\% for IDB in both approaches.

- The use of rolled section as reinforcement provided more shear strength than conventional deep beams.

- The deflection values at the ultimate failure load were similar for two conventional deep beams and in case of IDB, the ultimate load carrying capacity was nearly $8 \%$ more.

- The analytical and experimental deformation values were nearly similar.

- More accurate results of stress and deformation were obtained from an analytical study of Finite element modeling.

- When comparing the experimental and analytical results the specimen with the rolled I section reinforcement was more ductile, as the deformation was more.

- According to the Failure in IDB the expected composite action was observed, as the flexural failure was not a sudden failure, so it was preferable in case of deep beams. 


\section{Acknowledgement}

The authors would like to acknowledge to the Professors and Lab Technicians of Koneru Lakshmaiah Education Foundation, Guntur.

\section{References}

[1] J. D. Garay and A. S. Lubell,( 2008) "Behavior of Concrete Deep Beams with High Strength Reinforcement," Struct. Congr. 2008, vol. 5, no. 5, pp. 1-10,.

[2] M. R. Salamy, H. Kobayashi, and S. Unjoh,( 2007) "Experimental and analytical study on RC deep beam behavior under monotonic load," vol. 6, no. 205, p. 47,.

[3] Khan, M.A., Ahmed, F.S.,( 2013) "Effect Of Web Reinforcement On Ultimate Strength Of Reinforced Concrete Deep Beam," vol. 3, no. 3, pp. 516-519,.

[4] W. Y. LAM, (2004)"Seismic Performance of Plate Reinforced Composite Coupling Beams," in History, no. 316.

[5] L. Jiang, H. Zheng, Y. Liu, and X. Yuan, (2014)“Experimental investigation of composite steel plate deep beam infill steel frame," Int. J. Steel Struct., vol. 14, no. 3, pp. 479-488,

[6] M. Satyanarayana, (2017)"Strength and Durability Characteristics of Bacterial Mortar," no. September, pp. 228235,.

[7] B. of Indian Standards, ( 2005) "IS 875 (Part 3): Code of Practice for Design Loads (Other Than Earthquake) For Buildings and Structures. Part 3: Wind Loads (Second Revision),".

[8] B. of Indian Standards, "IS 456 (2000): Plain and Reinforced Concrete - Code of Practice."

[9] IS:1893,( 2002) "Criteria for Earthquake Resistant Design of Structures," Indian Stand., pp. 1-44,

[10] N. (Narayanan) Subramanian, Design of reinforced concrete structures. .

[11] M. Satyanarayana,( 2017) “Analysis and Design of Seismic Framed Structure," no. September, pp. 200-204,.

[12] M. S. Shetty, (2005)"Concrete technology: theory and practice". S. Chand,. 